Article

\title{
Extraordinary Funding and a Financially Viable Football Industry-Friends or Foes? A Norwegian Football League Perspective
}

\author{
Åse Jacobsen *, Morten Kringstad and Tor-Eirik Olsen
}

check for updates

Citation: Jacobsen, Å.; Kringstad, M.; Olsen, T.-E. Extraordinary Funding and a Financially Viable Football Industry-Friends or Foes? A Norwegian Football League Perspective. Sustainability 2021, 13, 2788. https://doi.org/10.3390/ su13052788

Academic Editors: Nicolas Scelles and Qi Peng

Received: 30 January 2021

Accepted: 25 February 2021

Published: 4 March 2021

Publisher's Note: MDPI stays neutral with regard to jurisdictional claims in published maps and institutional affiliations.

Copyright: (c) 2021 by the authors. Licensee MDPI, Basel, Switzerland. This article is an open access article distributed under the terms and conditions of the Creative Commons Attribution (CC BY) license (https:/ / creativecommons.org/licenses/by/ $4.0 /)$.
NTNU Business School, Norwegian University of Science and Technology, 7491 Trondheim, Norway; morten.kringstad@ntnu.no (M.K.); tor.e.olsen@ntnu.no (T.-E.O.)

* Correspondence: ase.jacobsen@ntnu.no

\begin{abstract}
Financial distress has been frequently addressed in the sports business and management literature; however, surprisingly little attention has been devoted to implications for financial viability derived from funding beyond what the Union of European Football Association (UEFA) defines as relevant income in football, henceforth referred to as extraordinary funding. This study critically discusses and reflects upon whether extraordinary funding can contribute to financial viability. To address this issue, we draw on approximately 100 financial statements for Norwegian top division clubs and their cooperating companies for three fiscal years. Results indicate that, although extraordinary funding contributes with sorely needed funds, thus from the outset contributing in making clubs more robust, the manner in which extraordinary funding occurs is still of great importance from a viability perspective. In this respect, it is useful to distinguish clearly between ex ante and ex post funding. While ex post funding can be argued to be counter-productive to financial viability (e.g., cloaking inadequate finances, providing incentives for overspending, and rewarding clubs that overspend), ex ante funding is more in line with sound financial management (e.g., funds that are contingent upon a history of sound finances, incorporated in budgets). One important implication of this study is that ex post funding can contribute to crowding out of good practices, as clubs that overspend can be rewarded for their actions by having funds injected ex post.
\end{abstract}

Keywords: sports business; extraordinary funding; financial viability; soft budgeting; financial statements

\section{Introduction}

Despite substantially increased revenues (e.g., [1,2]), European club football has not evaded financial distress, an issue also emphasised in [3] (p. 603), in which they claim that 'Insolvency is a systematic problem in the world of European soccer' (see also [4]). Another feature inherent to European football is the widespread use of external benefactors. A well-known example in this respect is Russian oligarch Roman Abramovich's ownership in the English Premier League (EPL) club Chelsea (see for example $[5,6]$ claimed that Abramovich had injected more than a billion Euros into the club. In other leagues, clubs have traditionally been funded by industrial enterprises, such as Bayer and Bayer 04 Leverkusen, Fiat and Juventus, and Philips and PSV Eindhoven [7,8]. Thus, investors and private benefactors inject vast amounts into the sport, as a means of financing sporting ambitions, keeping clubs alive and promoting private interests, such as gaining influence. Such excessive funding by benefactors provides a few clubs with a financial edge, leading to a distortion of the competition. Consequently, some have labelled it 'financial doping' (see for example [9]), an expression first used by the former UEFA (Union of European Football Associations, the governing body of European football) chief Lars Christer Olsson in the context of the implementation of the UEFA licensing system [10].

Both the scope of financial distress and excessive extent of external funds have fueled the need for financial interventions from regulatory bodies in Europe. In 2010, the UEFA 
introduced the Financial Fair Play Regulations (FFP) as an enhancement to the existing club licensing regulations. The main motivation in FFP is to improve the financial performance of European club football and to protect the long-term viability and sustainability (see Art. 2(2) therein). Consequently, the break-even requirement was added to increase the attention on achieving a sustainable balance between its income and expenses in the football market and to regulate the influence of external funding. FFP is a topic frequently discussed in the literature (e.g., [9,11-19]). Attitudes towards regulations, however, differ. While [20,21] suggest that such regulations are unnecessary due to the extremely low bankruptcy rates in European club football, [22] (p. 22) argues that, 'due to the specificities of professional football in Europe resulting in an environment where soft budget constraint (SBC) of the clubs prevail, regulation is deemed necessary to create a financial environment that does not punish clubs, in sporting terms, that are trying to balancing their books'.

Based on the UEFA Benchmarking Report [23], European club football seems to be recovering financially. In 2016, 26 of the 54 European leagues reported aggregated league profits, an improvement from only nine leagues in 2011. There are, however, indications of significant differences between leagues, as the UEFA Benchmarking Report highlights that the non-top 20 leagues' greater reliance on benefactors, transfer profits, and UEFA club competition prize money may lead to larger fluctuations in financial performance from year to year. Thus, there is a need to better understand the financial dynamics in the non-top 20 leagues, especially as FFP and the break-even rule targets only clubs of a certain size. For one, a deficit of $€ 5$ million over three years is considered an 'acceptable deviation'. For non-top 20 leagues, this constitutes a significant deficit. In addition, the break-even rule permits an accumulated deficit of up to $€ 30$ million over three years, if covered through equity injections. Subsequently, most non-top 20 leagues are too small to be assessed under the break-even rule.

Against this background, the main contribution of this study is that we address the issue of financial viability from a medium-sized European football league in Norway and analyse whether funding from benefactors, henceforth referred to as extraordinary funding, can help promote financial viability. Drawing on financial statements of Norwegian top division clubs for men in the period 2014-2016, we critically discuss and reflect upon whether extraordinary funding is beneficial for the financial viability of the football league. Our research question is as follows: Under what circumstances can extraordinary funding contribute to a financially viable football industry?

We define extraordinary funding as funding beyond FFP's definition of relevant income in football, which consists mainly of gate receipts, broadcasting, sponsorship, advertising, and commercial income [24]. More specifically, we distinguish between (i) capital injections, (ii) third-party ownership (TPO), and (iii) subordinated loans. Capital injections stem from various benefactors, such as private persons, companies, and local governments and thus resemble what $[25,26]$ refer to as money injections. Further, for the purpose of this paper, we address capital injections by distinguishing between share issue, sporadic capital donations, and regular subsidies. Third-party ownership (TPO) is the practice in which the ownership of players' economic rights is held by a third party [27], whereas subordinated loans are unsecured debt with the lowest priority.

Financial viability is, however, difficult to define clearly, and even more difficult to capture in practice. The latter probably explains why the sports literature is scarce in addressing financial viability per se. In its attempt to address finances in sports, different approaches have been employed, and the most critical one deals with bankruptcy (e.g., [28]). Others again have focused on insolvency (e.g., [3,4]). Rather than focusing on these, this study is concerned with financial viability in which sound financial management is of pivotal importance, especially in the long run. The stance taken is therefore that financial viability goes far beyond bankruptcy and insolvency. Although these are important, they are nonetheless primarily indicators of poor finances. In addition, they are by nature of an ex post character, and can thus be argued to be biased by portraying a more favourable financial situation than is the case. Equally important, financial indicators 
useful in predicting bankruptcy or insolvency include extraordinary funding and other types of funding not dealt with in this study. Thus, to address financial viability we suggest that a natural starting point is to analyse what has happened during the year by drawing on extraordinary funding, rather than looking at the end-of-year financial situation. It can also be argued that a financially viable football industry is fully compatible with bankruptcy or insolvency, primarily because this is contingent upon club management. This can thus be seen as a way to discourage other clubs from adopting similar poor financial strategies and is therefore self-sustaining. Interestingly, UEFA Club Licensing and Financial Fair Play Regulations [24] introduce the terms viability and sustainability, though without explicitly defining their respective content.

The paper is structured as follows. Section 2 gives an overview of the dynamics in the economics of European football, before addressing ownership objectives and regulations. The Section 3 describes the research design briefly, followed by Section 4 which gives a description of the Norwegian football context. In the next Section 5, empirical data are presented and analysed. Section 5 directs attention towards the discussions and conclusions in which implications of the study are included. Limitations and suggestions for future research are presented in Section 7.

\section{Background}

A professional sports league consists of teams not only competing with each other, but also cooperating in making products (i.e., matches) that are attractive to consumers (e.g., [29-31]). According to [32], an attractive sports league needs to be both sportingly and financially viable. Since the beginning of the millennium, there are examples of European football leagues in which teams have been put into administration, (e.g., Leeds United and Glasgow Rangers) and have even gone bankrupt (e.g., Lyn Oslo and Lyngby FC). Reviewing the literature addressing the finances in the big five European football leagues, [33] claimed that, apart from Germany, league profit is consistently negative.

Financial distress is not a new phenomenon in European football [3,20,28,32,34-37] and raises the intriguing question of why clubs struggle in balancing the books. Are there some common underlying mechanisms for financial distress in European football? The nature of professional sports leagues and ownership objectives are a natural starting point in this respect (see also, for example, [38] for descriptions of overinvestment environments in European football and [28] (p. 58) for 'The Causes of Insolvency in Professional Football').

\subsection{The Nature of a Team Sports League}

A professional team sport includes several underlying mechanisms which, by nature, may contribute to financial difficulties, most prominently envisaged by overspending. Inequality in drawing power, and hence revenues, is well documented in the literature (e.g., $[7,39,40])$. This implies that the club with the strongest drawing power obtains the highest financial contribution from the best player (i.e., the player's marginal revenue product) and is hence in a position to offer the highest wage, ceteris paribus. Therefore, the distribution of drawing power in a league is the main driver for the distribution of sporting performance [41], illustrated in the literature by the relationship between budgeted revenues and sporting performance [40]. Note that the level of market intervention is much lower in European football compared to the North American major leagues (e.g., [7,20]). The single most important driver for sporting success is players (sporting talent), an issue reflected in the literature on the relationship between pay and performance [42-46]. This suggests that it is tempting for clubs to attract players either to improve the initial sporting quality only based on drawing power or to keep the initial position (i.e., zerosum game (see, for example, [47])). Moreover, the process of attracting players strongly resembles an auction process, as the winner of the auction will theoretically be the club that offers the most. In an open sports market, these intertwined relationships might result in overspending and situations characterized as the winner's curse (see for example [48-50]) and thus contribute to financial distress. 
Traditionally, sporting prizes have been an integral part of professional team sports, European football certainly being no exception. In this respect, and different from the closed leagues in North America, the promotion and relegation system in Europe has been conveyed as a driving force for financial challenges and difficulties $[4,7,28,51]$. Over the years, the intensity for winning prizes based on regular season outcome has increased, attributable to the number of prizes and the financial payoff from prizes. As for the latter, according to UEFA.com (accessed on 30 January 2021), the distributed revenues for the Europa League increased from app. $€ 150$ millions in 2010/11 to $€ 560$ millions in 2019/20. In Norway, revenues for those participating in Europa League has more than doubled in the last five years (to illustrate, both Molde and Sarpsborg 08 finished last in their groups in the Europa League group stage in 2012/2013 and 2018/2019 respectively. While Molde received EURO 2.73 million [52], Sarpsborg 08 received EURO 5.94 million [53], showing that the distributed revenues had more than doubled in just five years). Moreover, the widespread use of sporting prizes and clubs' subsequent desire to attain prizes have been linked strongly to the so-called arms race in European football (e.g., [21,25,54]. As such, lucrative potential financial payoff (i.e., most prominently, qualifications to international club tournaments arranged by the UEFA) introduces further incentives to attract sporting talent (the club tournaments arranged by the UEFA can be viewed as post seasonal playoffs from the domestic regular season). Thus, lucrative sporting prizes can contribute to overspending, as the lure of potential payoff outweighs the risk of not attaining sporting prizes, which is consistent with the reasoning in [55].

\subsection{Ownership Objectives}

The relationship between pay and performance poses challenges for decision makers as increased spending is expected to be followed by better sporting performance, ceteris paribus. Hence, clubs experience a trade-off between sporting success and financial aims. In terms of ownership objectives, [34] characterized owners in European football as utility maximisers, whereas [41] assumed profit maximizing in major league baseball in North America (see [34] (p. 136) for the original objective function). In the prolonging of $[34,56]$ presented a simplified objective function by maximizing win percentage given a break-even condition (see, for example, [25] for a short discussion. Sporting and financial aims are mentioned in the North American literature as Sportsman-owner in [57] and later in, for example, [58]. Further, the same two elements can also be used in a broader discussion of institutional logics, as is shown in [59]). Based on a theoretical comparison with profit maximization, [56] argued that the former results in a higher demand for sporting talent and, subsequently, a higher wage level (see also [60,61]).

It is, however, worth noting that, among European football clubs, ownership structures differ. While some leagues, such as Denmark [62] and England [63], allow that clubs are limited companies, others such as Norway [62] require that football clubs are owned by members. Clubs in the latter category may face external pressure for focusing on sporting success above financial performance to a higher extent than clubs owned by investors, as members have no prospect of financial payback. Further, in these clubs, members of the board, and in some instances also directors, are usually elected by the club members. In this context, sporting success is a means of being re-elected [64].

Win maximisers, due to their break-even condition, operate on the financial brink and are therefore vulnerable to unfavourable variances in costs or revenues. In addition, it is possible that a club's ability to generate equity (i.e., retained earnings) is hampered. The same goes for being able to adapt to unfavourable variances (less slack). The latter is particularly relevant in this study, as football clubs can be characterized as being revenuesensitive, that is vulnerable to unfavourable changes in revenues, such as negative demand shocks $[3,4,28]$. This issue is highly topical due to the ongoing COVID-19 pandemic.

Based on the discussions above, financial distress is understandable. However, the conundrum in European football is related to abnormally high survival rates (e.g., $[4,22,65])$. [34,66] provided additional insight by introducing a general financial requirement in their models. 
Although this financial requirement, which can also be an acceptable loss, is difficult to justify from a financial perspective, the literature on soft budgeting (e.g., $[22,33,65,67]$ ) points to how and why this is feasible in practice. [65] claim that many European football clubs operate subject to a soft budget constraint, as investors, public authorities, and banks are willing to bail out clubs if necessary.

\section{Research Design}

The empirical data consists of financial statements for Norwegian football clubs in the top division and their cooperating companies. In addition, we also build on a report by Deloitte [68], based on the consolidated financial statements reported to the Norwegian Football Association (FA). While the Deloitte report primarily is drawn upon to give an overview of the finances for Norwegian top division clubs in 2016 and partly 2014 and 2015, the empirical data derived from the financial statements for Norwegian football clubs and their cooperating companies are used to address extraordinary funding for the period 2014-2016. The two aforementioned time periods do not correspond, as the first Deloitte report was published for the 2016 season. The process of obtaining financial statements was, however, not straightforward. Thus, we focus attention on describing in detail how empirical cases were selected, and why they were selected.

A total of 19 clubs participated in the Norwegian top division in the time period 20142016 and formed the starting point. Unfortunately, we encountered several difficulties in obtaining financial statements for clubs and their cooperating companies (limited companies). For one, the underlying challenge is that Norwegian football clubs are not obliged to make their consolidated financial statements publicly available. We were, however, able to extract club's financial statements from a public register called Brønnøysundregisteret. At the same time, in order to address extraordinary funding, we also needed financial statements for the cooperating companies as our main interest was centred on transactions between the football club and the cooperating companies. These transactions were pivotal to the approach adopted to address financial viability. Our reasoning here is that traditional financial key figures derived from end-of-year financial statements can be argued to be biased from a financial viability perspective, simply because extraordinary funding and other types of funding not dealt with in this study are included in the key figures. Thus, focusing on the transactions, characterized as extraordinary funding, during the year, provides important insights with respect to financial viability. However, as cooperating companies below a certain income limit were exempted from having publicly available financial statements, it was not possible to identify all financial statements. As a result, two clubs were excluded at this point. For the remaining 17 clubs we faced other difficulties in obtaining reliable empirical data. To illustrate, in several cases, financial statements were too aggregated to provide information necessary to capture transactions between clubs and cooperating companies. In other cases, revenues were not sufficiently specified, or specified at all, making it impossible to detect extraordinary funding. Thus, the detailed information required to accurately address extraordinary funding in a reliable manner thus reduced our empirical data. Ultimately, drawing on the financial statements we were able to identify extraordinary funding in twelve of the clubs. The analysis in Section 5 thus presents findings drawing on these clubs. In total, approximately 100 financial statements were analysed in the time period 2014-2016. Figure 1 provides an illustration of the data collection process as it unfolded, and also shows the clubs excluded at the different stages. 
All clubs in the Norwegian top division for the seasons 2014, 2015 and 2016 (In total 19 clubs)

Clubs included at this stage:

Aalesund, Bodø/Glimt, Brann, Haugesund, Lillestrøm, Mjøndalen, Molde, Odd, Rosenborg, Sandefjord, Sandnes Ulf, Sarpsborg 08, Sogndal, Stabæk, Start, Strømsgodset, Troms $\varnothing$, Viking and Vålerenga

Mjøndalen and Sandnes Ulf excluded due to lacking financial statements

Haugesund, Odd, Rosenborg, Sandefjord and Sogndal excluded due to difficulties in obtaining reliable empirical data or extraordinary funding not identified

The selection of empirical cases (clubs) to illustrate extraordinary funding in a reliable manner Clubs included at this stage:

Aalesund, Bodø/Glimt, Brann, Lillestrøm, Molde, Sarpsborg 08, Stabæk, Start, Strømsgodset, Tromsø, Viking and Vålerenga

Figure 1. The data selection process.

\section{The Case of Norwegian Football}

Historically, Norwegian football clubs have been structured as voluntary non-profit organizations, and full professionalism was first allowed in 1991. Norwegian league football is, like most European leagues, structured as a hierarchical system with promotion and relegation between the division levels. Based on revenues [68], the Norwegian top division can be characterized as a medium-sized European league. Since the millennium, Norwegian football has been subject to similar changes as other European leagues. Although total revenues have increased, the revenue mix has shifted as broadcast and commercial revenues overshadow matchday revenues. According to [68], commercial revenues accounted for $37 \%$ of total revenues in the 2016 season. Despite considerable overall growth in revenues, the Norwegian top division has not evaded financial distress. One plausible explanation is related to Norway being an exporter of player talent, implying that Norwegian football clubs have come to depend on player sales. To illustrate, although Norwegian football clubs had an operating profit (NOK 127 million) in the period 2009-2017, there would have been a substantial loss without player transfers (NOK 932 million).

Norwegian football has some unique features. For example, all football clubs are fully owned by their members. This implies that every member has an equal right vote in elections (i.e., board of directors). Clubs are, however, allowed to have formalized cooperation with limited companies. In Norway, this is referred to as the 'dual-model'. The principles in the dual model are illustrated in Figure 2 and show that the club can have ownership in subsidiaries (e.g., the pro shop and stadium), while the cooperating company can have a holding company and/or subsidiaries. Further, this clearly captures the motivation for the dual model related to the distinct separation between sporting activities, which are reserved for the club, and non-sporting activities, which are reserved for cooperating companies. The shadowed boxes represent those included in the consolidated financial statement, whereas the white boxes represent third-party ownership (TPO). 


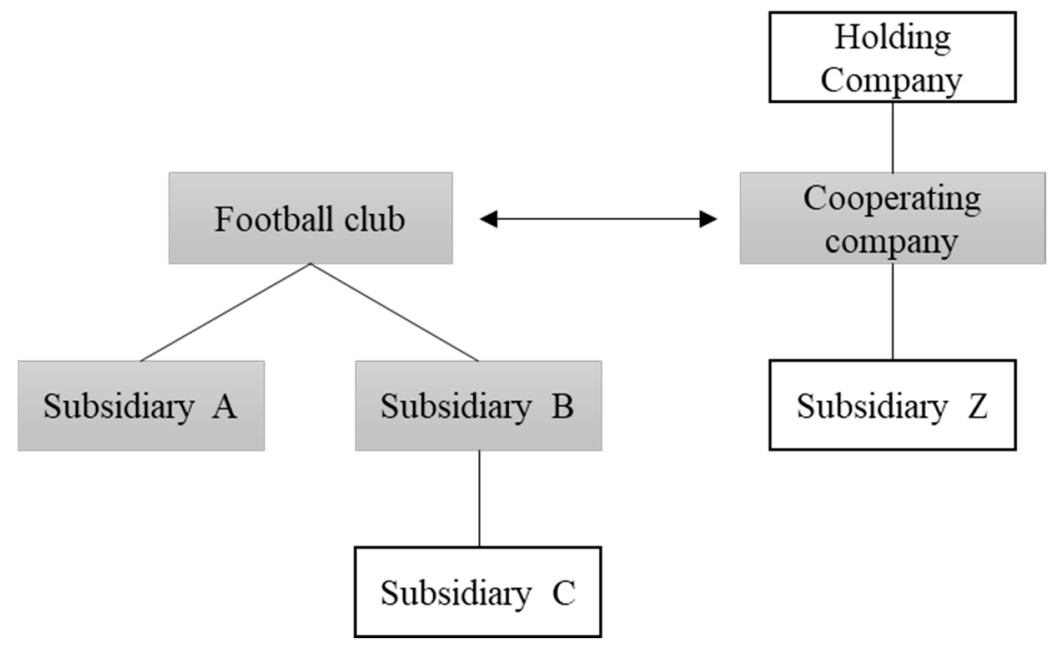

Figure 2. The Dual model [69].

\section{Analysis}

Based on the consolidated financial statements in the Deloitte report [68], Table 1 shows revenues, costs, net player transfers, and operating profit in the Norwegian top division for the years 2015-2016. Table 1 indicates large variations, as revenues span from NOK 36 million to NOK 219 million in $2015(1 \mathrm{EURO}=10$ NOK). Note, however, that the range in revenues is sensitive to participation and performance in the UEFA club tournaments, as well as to the outcome of the promotion/relegation process. It is also worth noting that operating profit is contingent upon player transfers.

Table 1. Revenues, costs, and operating profit (in NOK million) in the Norwegian top division 2015-2016. Range shows minimum and maximum values. Standard deviations for league average are in brackets (not available for 2014).

\begin{tabular}{|c|c|c|c|c|c|c|}
\hline & \multicolumn{2}{|c|}{$2016(N=16)$} & \multicolumn{2}{|c|}{$2015(N=16)$} & \multicolumn{2}{|c|}{$2014(\mathrm{~N}=16)$} \\
\hline & $\begin{array}{c}\text { League } \\
\text { Average (S.D.) }\end{array}$ & League Range & $\begin{array}{c}\text { League } \\
\text { Average (S.D.) }\end{array}$ & League Range & $\begin{array}{l}\text { League } \\
\text { Average }\end{array}$ & League Range \\
\hline Revenues & 85 (37) & 44-193 & $80(49)$ & 36-219 & 79 & $\mathrm{~N} / \mathrm{A}$ \\
\hline Costs & $89(38)$ & 49-195 & $82(47)$ & $34-204$ & 85 & $\mathrm{~N} / \mathrm{A}$ \\
\hline $\begin{array}{l}\text { Operating } \\
\text { profit before } \\
\text { NPT }\end{array}$ & $-4(11)$ & $-26-18$ & $-2(-9)$ & $-11-20$ & -5 & $\mathrm{~N} / \mathrm{A}$ \\
\hline $\begin{array}{l}\text { Profit player } \\
\text { transfers }\end{array}$ & $11(14)$ & $-3-49$ & $9(11)$ & $-1-34$ & 6 & $\mathrm{~N} / \mathrm{A}$ \\
\hline $\begin{array}{l}\text { Operating } \\
\text { profit }\end{array}$ & $7(14)$ & $-11-45$ & $8(9)$ & $-6-24$ & 1 & $\mathrm{~N} / \mathrm{A}$ \\
\hline
\end{tabular}

Source: [68].

Drawing on the Deloitte report [68], Table 2 presents the composition of the balance sheet by focusing on the league average as the starting point. Variation is in this respect a key property as portrayed by the standard deviations for the overall league average along with the considerable spans in range. Table 2 also shows that total assets are quite modest compared to the big leagues. To illustrate this, we draw on the UEFA Benchmark report 2016 [23]. As such, an average Norwegian top division team has total assets equal to $2.5 \%$ of an average English Premier League team's total assets. The corresponding number to the other Big five European football leagues (Spain, France, Germany and Italy) combined is $7.9 \%$. Another interesting observation from Table 2 is that tangible assets dominate, mainly because many clubs have majority stadium ownership. It should, however, be noted that 
player rights owned by third-party companies are not included in the club's consolidated balance sheet.

Table 2. Balance sheet Norwegian top division (average and range in NOK million).

\begin{tabular}{|c|c|c|c|c|c|c|c|c|c|}
\hline & \multicolumn{3}{|c|}{$2016(\mathrm{~N}=16)$} & \multicolumn{3}{|c|}{$2015(\mathrm{~N}=16)$} & \multicolumn{3}{|c|}{$2014(\mathrm{~N}=16)$} \\
\hline & $\begin{array}{c}\text { League } \\
\text { Average }\end{array}$ & $\begin{array}{l}\text { Per Cent } \\
\text { of Total } \\
\text { Assets }\end{array}$ & $\begin{array}{l}\text { League } \\
\text { Range }\end{array}$ & $\begin{array}{c}\text { League } \\
\text { Average }\end{array}$ & $\begin{array}{c}\text { Per Cent } \\
\text { of Total } \\
\text { Assets }\end{array}$ & $\begin{array}{l}\text { League } \\
\text { Range }\end{array}$ & $\begin{array}{c}\text { League } \\
\text { Average }\end{array}$ & $\begin{array}{l}\text { Per Cent } \\
\text { of Total } \\
\text { Assets }\end{array}$ & $\begin{array}{l}\text { League } \\
\text { Range }\end{array}$ \\
\hline $\begin{array}{l}\text { Intangible } \\
\text { assets } \\
\text { (player } \\
\text { registra- } \\
\text { tions) }\end{array}$ & 7 & $6 \%$ & $0-24$ & 4 & $5 \%$ & $\mathrm{~N} / \mathrm{A}$ & 6 & $5 \%$ & $\mathrm{~N} / \mathrm{A}$ \\
\hline $\begin{array}{l}\text { Tangible } \\
\text { assets }\end{array}$ & 83 & $70 \%$ & $0-328$ & 60 & $64 \%$ & $\mathrm{~N} / \mathrm{A}$ & 87 & $75 \%$ & $\mathrm{~N} / \mathrm{A}$ \\
\hline $\begin{array}{l}\text { Fixed } \\
\text { financial } \\
\text { assets }\end{array}$ & 5 & $4 \%$ & $0-35$ & 4 & $4 \%$ & $\mathrm{~N} / \mathrm{A}$ & 20 & $17 \%$ & $\mathrm{~N} / \mathrm{A}$ \\
\hline $\begin{array}{c}\text { Current } \\
\text { assets }\end{array}$ & 24 & $20 \%$ & $7-113$ & 26 & $27 \%$ & $\mathrm{~N} / \mathrm{A}$ & 4 & $3 \%$ & $\mathrm{~N} / \mathrm{A}$ \\
\hline $\begin{array}{c}\text { Total fixed } \\
\text { assets and } \\
\text { current } \\
\text { assets }\end{array}$ & 119 & $100 \%$ & $13-459$ & 95 & $100 \%$ & $\mathrm{~N} / \mathrm{A}$ & 116 & $100 \%$ & $\mathrm{~N} / \mathrm{A}$ \\
\hline Equity & 36 & $30 \%$ & $-1-265$ & 30 & $31 \%$ & $\mathrm{~N} / \mathrm{A}$ & 27 & $23 \%$ & $\mathrm{~N} / \mathrm{A}$ \\
\hline $\begin{array}{l}\text { Long-term } \\
\text { debt }\end{array}$ & 61 & $52 \%$ & $0-255$ & 41 & $44 \%$ & $\mathrm{~N} / \mathrm{A}$ & 66 & $57 \%$ & $\mathrm{~N} / \mathrm{A}$ \\
\hline $\begin{array}{c}\text { Current } \\
\text { liabilities }\end{array}$ & 22 & $18 \%$ & N/A-53 & 24 & $25 \%$ & $\mathrm{~N} / \mathrm{A}$ & 24 & $20 \%$ & $\mathrm{~N} / \mathrm{A}$ \\
\hline $\begin{array}{c}\text { Total } \\
\text { liabilities } \\
\text { and equity }\end{array}$ & 119 & $100 \%$ & $13-459$ & 95 & $100 \%$ & $\mathrm{~N} / \mathrm{A}$ & 116 & $100 \%$ & $\mathrm{~N} / \mathrm{A}$ \\
\hline
\end{tabular}

Equity also varies considerably, spanning from NOK minus one million to NOK 265 million. The biggest club, Rosenborg (Trondheim), accounts for $46 \%$ of the total league equity in 2016. Excluding Rosenborg, the average equity ratio drops to $22 \%$. The five biggest clubs, equity-wise, all have majority ownership in their stadium. Overall, the large variations make it difficult to compare the finances of Norwegian football clubs. However, Tables 1 and 2 together give insight related to financial risk.

From a win-maximizing perspective, low equity is risky due to unfavourable variances in revenues and/or costs. This suggests that a number of clubs are financially vulnerable. By introducing the equity/revenues ratio (see Table 3), the notion of vulnerability becomes apparent. Operating loss coupled with relatively low equity share signals a vulnerable financial situation in Norwegian football. Additionally, player wages constitute the largest cost for football clubs, which entails considerable financial risk given that a large proportion of costs are fixed in the short term. To illustrate, in 2016, the total wage costs for Norwegian football clubs were, on average, $53 \%$ of the revenues. 
Table 3. Revenues, equity, and equity/revenues ratio for the Norwegian top division clubs in 2016 (revenues and equity in NOK million).

\begin{tabular}{|c|c|c|c|c|c|c|}
\hline \multirow[b]{2}{*}{ Club } & \multicolumn{3}{|c|}{2016} & \multicolumn{3}{|c|}{2015} \\
\hline & Revenues & Equity & $\begin{array}{c}\text { Equity/Revenues } \\
\text { Ratio }\end{array}$ & Revenues & $\begin{array}{c}\text { Equity } \\
\text { (Calculated) }\end{array}$ & $\begin{array}{c}\text { Equity/Revenues } \\
\text { Ratio }\end{array}$ \\
\hline Rosenborg & 193 & 265 & $137 \%$ & 219 & $228 *$ & $104 \%$ \\
\hline Brann & 117 & 33 & $28 \%$ & & Second level & \\
\hline Molde & 117 & 81 & $69 \%$ & 159 & 77 & $48 \%$ \\
\hline Viking & 99 & 28 & $28 \%$ & 113 & 39 & $34 \%$ \\
\hline Strømsgodset & 91 & 26 & $29 \%$ & 95 & 20 & $21 \%$ \\
\hline Lillestrøm & 88 & 12 & $14 \%$ & 87 & $3 *$ & $3 \%$ \\
\hline Odd & 86 & 28 & $33 \%$ & 86 & 27 & $32 \%$ \\
\hline Sogndal & 84 & 37 & $44 \%$ & & Second level & \\
\hline Vålerenga & 82 & 6 & $7 \%$ & 81 & 3 & $4 \%$ \\
\hline Haugesund & 81 & 10 & $12 \%$ & 61 & 15 & $25 \%$ \\
\hline Aalesund & 63 & 11 & $17 \%$ & 61 & 9 & $15 \%$ \\
\hline Tromsø & 59 & 17 & $29 \%$ & 55 & 17 & $31 \%$ \\
\hline Start & 55 & 3 & $6 \%$ & 58 & -7 & $-12 \%$ \\
\hline Bodø/Glimt & 52 & 12 & $22 \%$ & 46 & 11 & $24 \%$ \\
\hline Stabæk & 48 & -1 & $-3 \%$ & 51 & 7 & $14 \%$ \\
\hline Sarpsborg08 & 44 & 11 & $25 \%$ & 40 & 6 & $16 \%$ \\
\hline
\end{tabular}

Source: [68]. Note: Equity for 2015 is calculated by subtracting operating profit for 2016 from equity 2016. This is a simplification as finance income and costs are not included. The latter is substantial in the two cases marked *. For Rosenborg the equity is derived from the official consolidated financial statements, while Lillestrøm is calculated simply by applying the relative change in equity percent between the two seasons on the absolute equity for 2016.

Based on Table 3, the majority of clubs have sufficient equity from the outset. However, given the operating loss shown in Table 1, the financial status appears to be uncertain, as some clubs operate on the financial brink. Further, when excluding net player transfers, both in 2015 and in 2016 more than 50\% of the Norwegian top division clubs would have generated an operating loss [68]. More importantly, this suggests that even small unfavourable variances can have major financial implications for clubs, in particular when equity is low. Assuming that costs are fixed in the short run, a 10\% drop in revenues would have resulted in negative equity for clubs such as Stabæk, Start (Kristiansand), and Vålerenga (Oslo). Overall, this shows that many clubs are revenue-sensitive, an issue certainly topical given the current COVID-19 pandemic.

Other measures, such as the Altman z-score, could also have been used to address financial vulnerability besides the equity/revenues-ratio. However juxtaposing equity and revenues can be argued to be a good proxy for financial vulnerability, at least for the aim in this study. As such, we introduce the equity/revenues-ratio to draw some overreaching conclusions on the finances in the Norwegian top division. The fact that Norwegian top division clubs are win-maximizing, and not profit-maximizing, coupled with the fact that the majority of costs can be viewed as fixed, at least in the short run, implies that revenues are essential in balancing the books. Thus, the equity/revenues-ratio is a satisfactory proxy for financial vulnerability as clubs facing a low equity/revenues-ratio are exposed to unfavourable changes in revenues and thus face the risk of losing their equity.

The purpose of the initial analysis has been to give an overview of the financial situation in Norwegian football. As such, the purpose is not to provide a foundation for generalizations, but rather to use the three years as a starting point to discuss if extraordinary funding can contribute to financial viability. We therefore direct attention to the empirics of dealing with extraordinary funding (drawing on the collected financial statements).

\subsection{Capital Injections}

Capital injections can be interpreted widely. For the purpose of this study, we make a clear distinction between share issue, sporadic capital donations, and regular subsidies. Table 4 provides an overview of capital injections in the Norwegian top division for the 
2015 and 2016 seasons and shows that capital injections constitute a significant proportion of the Norwegian top division clubs' financial resources. In 2015 and 2016, respectively, 7 and 8 of the 16 clubs on average received capital injections corresponding to $11 \%$ and $10 \%$ of revenues. It is, however, worth noting that the reliance of capital injections varies considerably. This is evident as capital injections accounted for $33 \%$ of revenues for Tromsø in 2015 and 26\% of revenues for Vålerenga in 2016. Another interesting feature in Table 4 is the unsystematic manner in which capital injections occur. While most clubs receive capital injections on a regular basis, Viking and Vålerenga went from no capital injections in 2015 to respectively NOK 17 million and NOK 21 million in 2016. Moreover, juxtaposing the two years for all clubs suggests that capital injections are characterized as both ex ante (e.g., Molde and Lillestrøm received the same amounts, respectively, in 2015 and 2016) and ex post (e.g., Viking). Overall, this shows that capital injections are an important funding source beyond football-related revenues. However, as capital injections are multi-faceted, we analyse and discuss issuing of shares, sporadic capital donations, and regular subsidies separately.

Table 4. A summary of identified cases of capital injections in the Norwegian top division (NOK million).

\begin{tabular}{ccc}
\hline Year & $\mathbf{2 0 1 5}$ & $\mathbf{2 0 1 6}$ \\
\hline Number of clubs & 7 & 8 \\
\hline Cases: & 0.6 & 1.2 \\
Aalesund & 19.9 & 10.1 \\
Brann & 2.1 & 2.1 \\
Lillestrøm & 13.4 & 13.4 \\
Molde & 1.0 & 1.7 \\
Sarpsborg 08 & 4.0 & 0.0 \\
Start & 18.3 & 7.7 \\
Tromsø & 0.0 & 17.0 \\
Viking & 0.0 & 21.0 \\
Vålerenga & 59.3 & 74.1 \\
\hline Total & $0.6-19.9$ & $1.2-21.0$ \\
\hline Range & 8.5 & 9.3 \\
\hline Average capital injection & $2 \%-33 \%$ & $2 \%-26 \%$ \\
\hline Range percent of revenue & $11 \%$ & $10 \%$ \\
\hline Average percent of revenue & & \\
\hline
\end{tabular}

\subsubsection{Share Issue}

Share issue is the process whereby a company passes on new shares to existing or new shareholders. This raises the company's equity, while also improving liquidity. In Norwegian football, the issuing of shares is performed by the club's cooperating company.

For issuing of shares, we draw on the case of Viking (Stavanger). At the end of 2015, Viking's combined equity (i.e., the aggregated numbers for the football club and the cooperating limited company) was approximately NOK 33 million. In 2016, revenues dropped from NOK 113 million to NOK 99 million, and the combined operating loss was about NOK 18 million, which accounted for more than half of the combined equity. Interestingly, the loss for the (cooperating) limited company exceeded the equity in the opening balance. This was dramatic given the one-year span, and equally important, a continuance the next year would have resulted in negative equity. It should be noted that this was partly attributable to non-sporting circumstances, in this case unusually low oil prices [68]. Nonetheless, to overcome the financially strained situation the limited company issued shares equivalent to NOK 17 million at the end of 2016. In this case, shares were issued ex post, suggesting it was a means to overcome the financial difficulties experienced by Viking. This case also highlights the revenue-sensitivity inherent to Norwegian football. 
Another example is derived from Tromsø. For 2014 and 2015, the aggregated consolidated loss in Tromsø was approximately NOK 10 million, equivalent to $8.7 \%$ of their revenues for the same period. Consequently, equity dropped considerably, and at the end of 2015, Tromsø experienced financial difficulties. To overcome the immediate crisis and to ensure positive equity, at an extraordinary general meeting on 24 December, the cooperating limited company decided to issue shares equal to NOK 14.3 million. This ensured positive equity (11.2 million). Interestingly, the timing for the issuing of shares clearly demonstrate that this was employed as a last resort to overcome a financial crisis.

Typically, investors invest in shares due to a potential future financial gain, but the analysis revealed no cases with payments of dividend. Thus, these cases illustrate how share issue in professional football can be interpreted as a donation rather than an investment, especially compared to investment in conventional shares.

\subsubsection{Sporadic Capital Donations}

Sporadic capital donations refer to situations where benefactors typically inject capital in an unsystematic manner. As such, sporadic capital donations resemble funding often associated with non-profit organizations, such as charitable organizations. Sporadic capital donations are recognized as revenues in the financial statements and therefore improve both operating profit and liquidity.

During 2016, Vålerenga struggled financially, particularly due to weak liquidity. To improve the financial situation, the majority shareholder in the cooperating limited company donated NOK 21 million to Vålerenga in 2016, equivalent to $26 \%$ of the consolidated revenues. The donation was recognized as increased revenues in the profit and loss account and helped Vålerenga report an operating profit of NOK 2.6 million. However, accounting for the modest consolidated equity by the end of 2016, NOK 6 million, the financial situation would have been critical without the donation, ceteris paribus.

Another example of sporadic capital injections draws on Brann (Bergen). Brann were somewhat surprisingly relegated after the 2014 season. This resulted in a substantial decrease in revenues in 2015. Brann nonetheless generated operating profit in both 2014 and 2015, an issue attributable primarily to considerable capital donations from a private person. More specifically, these amounted to NOK 19.9 million and NOK 21.7 million, respectively in 2014 and 2015. These sporadic donations accounted for respectively 17 and $21 \%$ of their revenues. Equally important, juxtaposing the magnitude of the capital donations to the consolidated equity at NOK 29 million at the end of 2015, suggests that the capital donations, ceteris paribus, helped prevent financial distress.

\subsubsection{Regular Subsidies}

Unlike sporadic capital donations, regular subsidies are conveyed as capital injections received on a regular basis. In the sports literature, subsidies are frequently associated with contributions from the public sector, typically in helping finance sports stadiums (e.g., [70]). Although this can be compared to both soft pricing and soft investments in the soft budgeting literature [33], the stance in this paper is that regular subsidies go beyond financing stadiums, and equally important, it can involve injections from private persons and companies. This is in line with the reasoning in [8] (p. 275), emphasising that subsidies 'encompass public subsidies by local authorities, private donations, and funds redistributed to clubs by sports federations. The systematic manner in which regular subsidies occur also implies that these are ex ante by nature and thus likely to be incorporated in planning activities, most prominently budgets.

Start (Kristiansand) is one of the clubs that have received regular subsidies. After relegation from the Norwegian top division in 2016, Start signed a deal with an investor (company) in July 2017 (this company is outside the club, which means that it is neither a (dual-model) cooperating company nor a TPO company). This deal provides Start with NOK 40 million over a ten-year period. NOK 10 million was disbursed at the signing date, while the remaining amount is distributed annually over the next 10 years. 
Another example is taken from one of the biggest clubs in terms of revenues, Molde. Through two cooperating limited companies, Molde annually receives regular subsidies of approximately NOK 13.4 million. In 2016, this accounted for $11 \%$ of the consolidated revenues. As the financial situation in Molde has been healthy, with an aggregated operating profit of NOK 15 million in the period 2014-2016, the motivation of these regular subsidies is presumably not to prevent financial distress, but rather to give the club some financial edge over its competitors.

\subsection{Third-Party Ownership}

Third-party ownership (TPO) involves private persons or companies buying and owning the financial rights of football players. Compared to capital injections, this is a more indirect type of extraordinary funding. TPO has been highly controversial and was banned by FIFA in May 2015. In Norway, TPO is still possible, though with some reservations [71]. In the 2016 season, 6 of the 16 clubs in the Norwegian top division used a TPO company to finance investments in player rights. Drawing on Strømsgodset (Drammen), Table 5 shows the different companies cooperating with Strømsgodset, along with the book value and amortization of player rights for each company. Interestingly, although all three companies have ownership in player rights, only Strømsgodset Fotball Ltd. is included in the consolidated statements. In the period 2014 to 2016, the amortization of player rights totals about NOK 17.9 million. However, because Drammenspatriotene Ltd. and Meetball Ltd. are not included in the consolidated financial statements, Strømsgodset avoided a cost of NOK 9.9 million. The use of TPOs to invest in player rights has therefore helped mitigate financial risk, as there are no costs for the club related to financing player rights (i.e., interest costs). In addition, the use of TPOs can be a means for heavy investments in player rights, at least compared to traditional lending arrangements. The club, however, runs the risk of not cashing in on future player sales.

Table 5. Strømsgodset 2014-2016 (NOK million).

\begin{tabular}{cccccccc}
\hline & \multirow{2}{*}{ Consolidated } & \multicolumn{2}{c}{ Book Value of Player Rights } & \multicolumn{2}{c}{ Amortization of Player Rights } \\
\cline { 3 - 8 } & & $\mathbf{2 0 1 6}$ & $\mathbf{2 0 1 5}$ & $\mathbf{2 0 1 4}$ & $\mathbf{2 0 1 6}$ & $\mathbf{2 0 1 5}$ & $\mathbf{2 0 1 4}$ \\
\hline Strømsgodset & Yes & 0 & 0 & 0 & 0 & 0 & 0 \\
Strømsgodset Fotball Ltd. & Yes & 10.2 & 5.6 & 4.1 & 4 & 2.5 & 1.5 \\
Drammenspatriotene Ltd. & No & 1 & 2.7 & 4.8 & 1.7 & 2.1 & 2 \\
Meetball Ltd. & No & 0.6 & 1.6 & 3 & 1 & 1.3 & 1.8 \\
\hline
\end{tabular}

Note: Ltd. is translated from the Norwegian terminology 'AS'.

Bodø/Glimt, one of the lesser football clubs in terms of revenues, adopted a similar approach. Table 6 shows that Bodø/Glimt generated a marginal operating profit (ranging from NOK 0.7 million to NOK 1.2 million) each year in the period 2014 to 2016. The TPO company, Nordlandsglimt, was not included in the consolidated statements and their considerable operating losses in the period did not influence the finances in Bodø/Glimt. This example shows that Bodø/Glimt's financial situation would have been far more strained if the TPO company had been included in the consolidated financial statements for Bodø Glimt. 
Table 6. Bodø/Glimt and Nordlandsglimt Ltd. (NOK million).

\begin{tabular}{|c|c|c|c|c|c|c|}
\hline & \multicolumn{3}{|c|}{ Bodø/Glimt } & \multicolumn{3}{|c|}{ Nordlandsglimt Ltd. } \\
\hline & 2016 & 2015 & 2014 & 2016 & 2015 & 2014 \\
\hline Amortization of player rights/squad & 0 & 0 & 0 & 3.3 & 4.1 & 4.1 \\
\hline Operating profit/(loss) & 0.7 & 0.9 & 1.2 & $(1.6)$ & $(1.0)$ & $(4.6)$ \\
\hline \multicolumn{7}{|l|}{ Player transactions } \\
\hline Additions & 0 & 0 & 0 & 2.7 & 1.8 & 4.6 \\
\hline Disposals & 0 & 0 & 0 & $(4.8)$ & $(1.0)$ & $(0.2)$ \\
\hline Book value player rights (end of year) & 0 & 0 & 0 & 9.2 & 9.9 & 12.2 \\
\hline Book equity (end of year) & 11.7 & 10.9 & 9.9 & 7.6 & 9.2 & 10.2 \\
\hline
\end{tabular}

To further illustrate the use of TPO, we draw on Brann. In the annual report for the financial year 2015, the club states that two TPO companies were involved in the signing of four players. Given the club's financial situation at this point, with decreased revenues due to relegation, this helped the club increase their sporting quality in a financially demanding situation. In fact, the board of directors' report explicitly states that these signings would not have been possible without the support from TPO companies.

\subsection{Subordinated Loan}

The last type of extraordinary funding dealt with in this study is subordinated loans, which is defined as an unsecured debt with lowest priority. It is also important to note that a subordinated loan is part of the club licence defined equity [69]. In turn, this equity is defined as the total of book equity and subordinated loan (additional to some other possibilities). Interestingly, this suggests that subordinated loans are tempting to draw in order to overcome negative equity.

For the period 2014-2016, two Norwegian clubs have reported negative equity on four occasions: Start in 2014 and 2015 and Stabæk in 2014 and 2016. To avoid sanctions and, at worst, relegation, they drew on subordinated loans from local governments or private entities. Interestingly, but perhaps not surprising per se, subordinated loans were employed on an ex post basis, providing further evidence of subordinated loans being a last resort to ensure positively defined equity. Further, it is no coincidence that, more than often, local governments are the ones providing subordinated loans to clubs. This shows that clubs can exert pressure on local governments for bailouts, as the alternative is bankruptcy. Thus, paradoxically, the bankruptcy option leaves clubs in a favourable position negotiation-wise. However, such public funding is problematic from a welfare economics perspective, as the burden is transferred to the taxpayers.

\section{Discussion and Conclusions}

The initial financial analysis suggested that Norwegian football clubs, at least on average, were characterized as seemingly healthy, financially speaking. It is, however, important to note that the diverse types of extraordinary funding are included in the financial figures. The implication derived from this is that financial figures presented early on are bound to be somewhat inflated. Equally important, the empirical findings on extraordinary funding have been treated separately. Combining these is therefore necessary to get a better understanding of extraordinary funding in relation to financial viability. Recall, however, that the main purpose of this study is to address this issue using financial statements for football clubs and their cooperating companies. The aim is therefore not to generalize findings as such but rather to offer some interesting perspectives on the complex relationship between finances in football and financial viability by drawing on extraordinary funding as a phenomenon.

As such, this study clearly shows that several different types of extraordinary funding are in play, and that football clubs seem to have wide discretion on how to obtain additional 
funding. Interestingly, but not surprisingly, the different types of extraordinary funding are not mutually exclusive, evidenced by the fact that numerous football clubs draw on several types in conjunction (e.g., Tromsø and Start). More important, this suggests that different benefactors are involved, including private persons, companies, and local governments. In addition, making a clear distinction between different types of extraordinary funding, and treating these as isolated from one and other, creates a false impression of the actual magnitude of the finances of football clubs attributable to extraordinary funding as a whole. Rather, we argue that extraordinary funding as a phenomenon constitutes a rather significant proportion of total league revenues. Extraordinary funding as portrayed in this study is, however, multifaceted. Thus, it is misleading to argue that it is negative for financial viability as such. Based on the empirical findings and the literature reviewed, we offer a nuanced view on this matter in the following sections.

As a starting point, it is possible to argue that the extraordinary funding is problematic from the outset as it stems from non-footballing activities. This is made more topical, as this study does not depict absolutely all types of non-footballing related funding. To illustrate, local governments helping to finance stadiums and annulments of debt, just to mention a few, are beyond the scope of this study. It is also possible to argue that extraordinary funding, regardless of its character, is beneficial simply because it brings money to the sports [21]. However, this is naive, and a more critical approach is warranted from a financial viability perspective.

Juxtaposing the different types of extraordinary funding dealt with in this study, some important issues stand out. For one, and consistent with the reasoning in FFP, the distinction between ex ante funding and ex post funding is of great importance. From a management accounting perspective, the latter can, in many instances, be characterized as ways to overcome a desperate financial situation. Relevant in this respect, [72] (p. 442) claimed that 'financial disaster often is averted only because of donations from boosters'. This study provides examples that resemble rescue missions, most notably related to share issuing but also related to sporadic capital donations. In general, problems related to extraordinary funding made ex post can be linked to the soft budgeting literature (e.g., [22,65]). As such, extraordinary funding made ex post only contributes to cloaking the fundamental problems in practice, namely inadequate management accounting and control. Put differently, if there are no sanctions due to inadequate finances, what is really at risk for clubs? Interestingly, [49] (p. 14), drawing on the French Ligue 1, claimed that 'clubs' budget constraints will remain soft as long as the threat of bankruptcy or definitive liquidation continues to be more a potential rather than a real practical perspective'. Thus, the extremely high survival rate, is not a reflection of sound financial management, but rather attributable to someone bailing out clubs. This, in turn, raises the all-important question related to team sports: can we expect clubs to learn from their mistakes if 'escape routes' are easily available? Against this background, our study shows that several clubs have repeatedly drawn on different types of extraordinary ex post funding mainly to overcome financial distress, an issue certainly not compatible with long-term financial viability. On the contrary, and in line with the reasoning in [73], ex post funding can result in risk escalation, as clubs may come to take on extensive risk by gambling on sporting success. Similarly, [26] showed that the possibility of being bailed out induces decision makers in clubs to take riskier investment decisions. Put differently, the findings in $[26,73]$ suggest that the attitude towards risk and the perception of it are altered. In terms of our empirical data, this can help explain why some Norwegian football clubs have made repeatedly use of ex post funding. This is nonetheless unfortunate in terms of financial viability. Evidence from the soft-budgeting literature emphasize that a major problem is related to dysfunctional behaviour [25]. Rescue missions, such as share issues, provide football clubs with no incentives to reduce spending. In contrast, by spending more money, they are simply likely to obtain funding they otherwise would not receive, an issue certainly harmful for financial viability. It is plausible to argue that ex ante expectations of ex post extraordinary funding, if clubs experience financial difficulties, 
will have unfortunate implications by encouraging behaviour, and hitherto decisions and actions, that is counterproductive to financial viability. Against this background, a worstcase scenario is that this will favour clubs that are prone to overspending and subsequently contribute to the diffusion of non-viable strategies. Although hardening devices such as the abolishment of TPO and the dissolution of ex post funding have a potential to prevent such strategies, the empirical data drawing on Norwegian football clubs offer little support in this respect.

In a similar vein, considering the strong interdependency within a league (e.g., $[29,74])$ gives additional insights into problematic issues related to ex post funding in general and, more specifically, overspending. In line with the pay and performance literature (e.g., [42-46]), overspending made possible partly by ex post funding is likely to trigger increased spending also by other clubs (e.g., zero-sum game). This implies that football clubs focusing on sound financial management may, in fact, end up suffering sporting-wise and subsequently also financially due to worsened sporting results, including missing out on sporting prizes ([47] show on the basis of [75] that for the Scottish Premier League in football for the $2000 / 2001$ season, the only club reporting a positive operating profit finished last in the league). Relevant in this context, [73] suggested that clubs operating with a hard budget constraint are left with two options: accept sportive decline or operate with a soft budgeting constraint. This in turn implies that poor practices are likely to be diffused among football clubs, as clubs focusing on sound financial management are crowded out by clubs that are allowed to operate under soft budget constraints. This results in adaptations counter-effective to the financial integrity of the football industry. $[25,76]$ went as far as to label the competition in football as a 'zombie race' since competitors are technically bankrupt. Thus, the fundamental problems lie herein, as most clubs are not in a situation where they face a hard budget constraint.

Ex ante extraordinary funding, most prominently regular subsidies, is, from a financial perspective, less problematic in terms of financial viability. Regular subsidies are likely to be part of the planning process and thus incorporated in the budgeting process and consequently more in line with sound financial management. Secondly, future funding is contingent upon a history of sound financial club management. Thus, in the absence of good housekeeping, clubs may curtail future possibilities of extraordinary funding received ex ante, an issue that provides incentives that promote sound investment decisions. From this perspective, ex ante extraordinary funding is compatible with financial viability. However, there are still reasons for concern. For one, it can cause financial slack, as clubs may come to depend on ex ante funding (see for example [77]). Given the current COVID-19 pandemic, the financial goodwill from private persons and companies should not be taken for granted. For cyclical upturns, this is not necessarily a problem. Cyclical downturns in conjunction with the revenue-sensitive nature inherent to football is, however, potentially harmful to the financial viability per se. Furthermore, in cases with public funding the burden is placed on the taxpayers which is problematic from a welfare economics perspective.

This study shows that addressing extraordinary funding and financial viability is a complex, yet important, issue. Despite rather limited empirical data, this study contributes to the ongoing debate on football finances and financial viability (e.g., [3,4,28,37,74]). Based on the empirical data, we argue that extraordinary funding per se is not negative, primarily because it brings sorely needed money to the sport. However, we argue that the manner in which extraordinary funding is drawn upon is of great importance and that it has direct as well as indirect implications for financial viability. As for the direct implications, these are most prominently attributable to ex post extraordinary funding. The empirical data show that in the case of share issue, extraordinary funding ex post can be seen as rescue missions, i.e., funding drawn upon solely to overcome financially desperate situations. As for the indirect effects, these are also closely related to extraordinary funding ex post, but go beyond, as these are concerned with the behavioural implications derived from the availability of extraordinary funding. Examples stressed in this study emphasize 
problematic issues related to its potential of altering attitude towards risk, the diffusion of overspending strategies, and the diffusion of poor practices, issues that coincide with the reasoning in the soft budgeting literature. Balancing the injection of money to the sport and the long-term financial viability of the sport is therefore a delicate matter that requires unique understanding, more specifically on how different types of extraordinary funding are used, and hitherto their implications on club behaviour in relation to financial viability.

This study issues a call for regulatory bodies to take on a proactive role in promoting financial viability, primarily by providing incentives for decisions, such as those related to extraordinary funding, that are in line with sound financial management. This requires that regulatory bodies understand the ways in which football clubs can attract additional funding, also beyond those dealt with in this study. Equally important, regulatory bodies need to understand the implications on financial viability that can be derived from different types of funding. Although trivial, the empirical data on subordinated loans clearly illustrate that this is lacking in practice. The availability of subordinated loans, as part of the financial reporting that clubs are obliged to report on to the Norwegian FA, at best sends mixed signals and at worst rewards poor practices. As for the latter, it is evident that the answer to overcome negative equity, paradoxically enough, is to borrow more money (a subordinated loan). Subordinated loans thus provide clubs with an exit opportunity if things get out of hand, financially speaking. To make matters worse, clubs are made aware of this exit opportunity in the financial reporting system provided by the regulatory body, in this case, the Norwegian FA [69].

In the prolonging of this, it is worth noting that Financial Fair Play (FFP) has prohibited clubs from drawing on ex post funding. Simultaneously, FFP has been criticized for providing clubs incentives to convert ex post funding to ex ante funding $[73,76]$. This in turn implies that clubs adapt to regulatory demands in ways not necessarily in line with financial viability. The key to effective regulations is therefore to understand and consequently anticipate how clubs will respond to changes in regulations. For regulatory bodies, however, the cost of regulations can be substantial, a point emphasized in [21] (p. 223) on European football, as it is claimed that "misdirected regulations that undermine efficiency also have the potential to drive resources away from Europe". For regulatory bodies, the balance between maintaining an attractive sport and financial viability is therefore difficult in practice. This is made even more difficult as an attractive sport is contingent upon several issues, in which competitive balance is pivotal. Although not addressed explicitly in this paper, extraordinary funding is also likely to have implications for the competitive balance of sports leagues [11,17-19].

Another implication is that the financial status goes far beyond bankruptcy rates. This implies that (extremely) low bankruptcy rates is per se not a satisfactory indicator of the financial situation of clubs or the league. This study shows that going beyond the key financial figures, often found in financial regulations, is necessary to better grasp the financial situation of clubs as well as the league as a whole. Thus, financial figures contain too much noise, due to the inclusion of extraordinary funding, to mirror the financial situation in an informative manner.

\section{Limitations and Suggestions for Future Research}

Despite the rather limited empirical data in this study, the study would benefit from richer empirical data in the sense that it would be possible to unveil patterns related to the use of extraordinary funding, e.g., whether the use of extraordinary funding is increasing over the long-term or whether certain types of extraordinary funding are more frequently employed than others. This would have allowed for a comprehensive and complete mapping of extraordinary funding as a phenomenon. In practice, however, this is not possible as the complete financial statements are reserved for the Norwegian Football Association. As this study builds on a unique ownership model, it also provides a promising avenue for future research by comparing results across countries with different ownership models. Interestingly, in a similar vein, based on their co-citation bibliometric 
analysis, [78] propose comparing membership-owned clubs in Spain (e.g., FC Barcelona and Real Madrid CF) with European football clubs organized as limited companies.

Based on the findings in this study, several other issues should also be addressed in future research. For one, there is a need to understand the decision-making processes in football clubs in practice (e.g., by applying agency theory), and in particular how football clubs balance sporting ambitions and finances in general, including extraordinary funding and financial regulations. From a theoretical perspective, institutional logics and a focus on competing logics (e.g., [59]) would be a natural starting point in this respect. In addition, studies should aim at understanding the conditions that trigger specific types of extraordinary funding, as this would allow for a more effective regulation of football clubs in the sense that funding depicted as a threat to the financial viability of football clubs (e.g., rescue missions) could be avoided at large. Future research should also focus on funding sources not dealt with in this study, such as those related to financing stadiums, as these are of a substantial financial character. In addition, the effects of extraordinary funding and other funding sources on competitive balance are interesting and worthy of future investigation.

Author Contributions: All authors (Å.J., M.K., T.-E.O.) contributed to write all the paragraphs of the entire paper. Å.J., however, collected the data (financial statements) utilized in this paper and was also the author advocating the initial research idea. Supervision by M.K., T.-E.O. All authors have read and agreed to the published version of the manuscript.

Funding: This research received no external funding.

Data Availability Statement: Publicly available financial statements were analysed in this study. These financial statements can be found here: https:/ / www.brreg.no/ (accessed on 30 January 2021).

Conflicts of Interest: The authors declare no conflict of interest.

\section{References}

1. Solberg, H.A.; Jacobsen, Å.; Jakobsen, T.G. Media rights in professional club football. In Managing Sport Business: An Introduction, 2nd ed.; Hassan, D., Ed.; Routledge: Abingdon, Oxon; Taylor \& Francis Group: New York, NY, USA, 2018; pp. $319-345$.

2. Deloitte. Annual Review of Football Finance 2020; Sport Business Group: Manchester, UK, 2020.

3. Scelles, N.; Szymanski, S.; Dermit-Richard, N. Insolvency in French soccer: The case of payment failure. J. Sport Econ. 2018, 19, 603-624. [CrossRef]

4. Szymanski, S. Entry into exit: Insolvency in English professional football. Scot. J. Polit. Econ. 2017, 64, 419-444. [CrossRef]

5. Scelles, N.; Helleu, B.; Durand, C.; Bonnal, L. Professional sports firm values: Bringing new determinants to the foreground? A study of European soccer, 2005-2013. J. Sport Econ. 2016, 17, 688-715. [CrossRef]

6. Gibson, O. Chelsea Record Their First Profit of the Roman Abramovich Era". The Guardian 2012. Available online: http: / /www.guardian.co.uk/football/2012/nov/09/chelsea-record-profit-roman-abramovich-era (accessed on 30 January 2021).

7. Hoehn, T.; Szymanski, S. The Americanization of European football. Econ. Policy 1999, 14, 204-240. [CrossRef]

8. Andreff, W.; Staudohar, P. The evolving European model of professional sports finance. J. Sport Econ. 2000, 1, 257-276. [CrossRef]

9. Müller, J.C.; Lammert, J.; Hovemann, G. The financial fair play regulations of UEFA: An adequate concept to ensure the long-term viability and sustainability of European club football? Int. J. Sport Finance. 2012, 7, 117-140.

10. UEFA. Club Licensing Vital, Says Olsson. 2004. Available online: www.uefa.org/protecting-the-game/club-licensing-andfinancial-fair-play/news/newsid=157594.html (accessed on 30 January 2021).

11. Vöpel, H. Do We Really Need Financial Fair Play in European Club Football? An Economic Analysis. CESifo DICE Report 2011, 9 , 54-59.

12. Drut, B.; Raballand, G. Why Does Financial Regulation Matter for European Professional Football Clubs? Int. J. Sport Manag. Mark. 2012, 11, 73-88. [CrossRef]

13. Hamil, S. Financial Fair Play—Why Loss-Making Is a Problem: The Example of the English Football League. In Political Economics. Competition and Regulation: Vol. 14. Contemporary Research in Sports Economics, Proceedings of the 5th ESEA Conference 2014; Budzinski, O., Feddersen, A., Eds.; Peter Lang: Frankfurt am Main, Germany, 2012; pp. 35-56.

14. Morrow, S. Financial Fair Play: Implications for Football Club Financial Reporting; Institute of Chartered Accountants of Scotland: Edinburgh, UK, 2014.

15. Schubert, M. Potential agency problems in European club football? The case of UEFA Financial Fair Play. Sports Bus. Manag. 2014, 4, 336-350. [CrossRef]

16. Madden, P. Welfare Economics of "Financial Fair Play" in a Sports League with Benefactor Owners. J. Sport Econ. 2015, 16, 159-184. [CrossRef] 
17. Sass, M. Glory Hunters, Sugar Daddies, and Long-Term Competitive Balance under UEFA Financial Fair Play. J. Sport Econ. 2016, 17, 148-158. [CrossRef]

18. Freestone, C.J.; Manoli, A.E. Financial fair play and competitive balance in the Premier League. Sports Bus. Manag. 2017, 7, 175-196. [CrossRef]

19. Plumley, D.; Ramchandani, G.M.; Wilson, R. The unintended consequence of Financial Fair Play: An examination of competitive balance across five European football leagues. Sports Bus. Manag. 2019, 9, 118-133. [CrossRef]

20. Peeters, T.; Szymanski, S. Financial Fair Play in European Football. Econ. Policy 2014, 29, 343-390. [CrossRef]

21. Szymanski, S. Fair is foul: A critical analysis of UEFA financial fair play. Int. J. Sport Financ. 2014, 9, 218-229.

22. Storm, R.K. The need for regulating professional soccer in Europe: A soft budget constraint approach argument. Sports Bus. Manag. 2012, 2, 21-38. [CrossRef]

23. UEFA. The European Club Footballing Landscape-Club Licensing Benchmarking Report Financial Year 2016. 2017. Available online: www.uefa.com/MultimediaFiles/Download/OfficialDocument/uefaorg/Clublicensing/02/53/00/22/2530022_ DOWNLOAD.pdf (accessed on 30 January 2021).

24. UEFA. UEFA Club Licensing and Financial Fair Play Regulations. 2018. Available online: https://documents.uefa.com/v/u/ MFxeqLNKelkYyh5JSafuhg (accessed on 30 January 2021).

25. Franck, E. Financial fair play in European club football: What is it all about? Int. J. Sport Financ. 2014, 9, 193-217. [CrossRef]

26. Franck, E.; Lang, M. A theoretical analysis of the influence of money injections on risk taking in football clubs. Scot. J. Polit. Econ. 2014, 61, 430-454. [CrossRef]

27. FIFA. Third-Party Ownership of Players' Economic Rights. 2015. Available online: https://img.fifa.com/image/upload/w1 tltvr7omt2mqt1cobd.pdf (accessed on 30 January 2021).

28. Szymanski, S.; Weimar, D. Insolvencies in Professional Football: A German Sonderweg? Int. J. Sport Finance 2019, 14, 54-68. [CrossRef]

29. Neale, W.C. The peculiar economics of professional sports. Q. J. Econ. 1964, 78, 1-14. [CrossRef]

30. Gerrard, B. Media ownership of pro sports teams: Who are the winners and losers? Int. J. Sport. Mark. Spons. 2000, 2, 20-39. [CrossRef]

31. Késenne, S. The Economic Theory of Professional Team Sports. An Analytical Treatment; Edward Elgar Publishing Limited: Cheltenham, UK; Northampton, MA, USA, 2007.

32. Gerrard, B. Still up for grabs? Maintaining the sporting and financial viability of European Club Soccer. In International Sports Economics Comparisons; Fort, R., Fizel, J., Eds.; Greenwood Publishing Group: Westport, Ireland, 2004; pp. $39-59$.

33. Nielsen, K.; Storm, R.K. Profits, championships and budget constraints in European professional sport. In When Sport Meets Business-Capabilities, Challenges, Critiques; Wagner, U., Storm, R.K., Nielsen, K., Eds.; Sage: London, UK, 2017 ; pp. 153-166.

34. Sloane, P.J. The economics of professional football: The football club as a utility maximiser. Scot. J. Polit. Econ. 1971, 18, 121-146. [CrossRef]

35. Bird, P.J. The demand for league football. Appl. Econ. 1982, 14, 637-649. [CrossRef]

36. Janssens, P.; Késenne, S. Belgian football attendances. Tijds. Econ. Manag. 1987, 32, 305-315.

37. Dermit-Richard, N.; Scelles, N.; Morrow, S. French DNCG management control versus UEFA Financial Fair Play: A divergent conception of financial regulation objectives. Soccer Soc. 2019, 20, 408-430. [CrossRef]

38. Ruta, D.; Lorenzon, L.; Sirone, E. The relationship between governance structure and football club performance in Italy and England. Sports Bus. Manag. 2019, 10, 17-37. [CrossRef]

39. Dobson, S.; Goddard, J. Revenue Divergence and Competitive Balance in a Divisional Sports League. Scot. J. Polit. Econ. 2004, 51, 359-376. [CrossRef]

40. Kringstad, M.; Olsen, T.E. Can sporting success in Norwegian football be predicted from budgeted revenues? Eur. Sport Manag. Q. 2016, 16, 20-37. [CrossRef]

41. Rottenberg, S. The baseball players' labor market. J. Polit. Econ. 1956, 64, 242-258. [CrossRef]

42. Szymanski, S.; Smith, R. The English football industry: Profit, performance and industrial structure. Int. Rev. Appl. Econ. 1997, 11, 135-153. [CrossRef]

43. Szymanski, S.; Kuypers, T. Winners and Losers: The Business Strategy of Football; Viking Books: London, UK, 1999.

44. Hall, S.; Szymanski, S.; Zimbalist, A.S. Testing causality between team performance and payroll: The cases of Major League Baseball and English soccer. J. Sport Econ. 2002, 3, 149-168. [CrossRef]

45. Gerrard, B. Analysing the win-wage relationship in pro sports leagues: Evidence from the FA Premier League, 1997/98-2001/02. In Sports Economics after Fifty Years: Essays in Honour of Simon Rottenberg; Rodrígues, O., Késenne, S., García, J., Eds.; Oviedo University Press: Oviedo, Spain, 2006; pp. 169-190.

46. Fort, R. Sports Economics, 3rd ed.; Prentice Hall: Boston, MA, USA, 2011.

47. Solberg, H.A.; Haugen, K.K. European club football: Why enormous revenues are not enough? Sport Soc. 2010, 13, 329-343. [CrossRef]

48. Andreff, W. The Winner's Curse in Sports Economics. In Contemporary Research in Sports Economics; Budzinski, O., Feddersen, A., Eds.; Peter Lang Academic Research: Frankfurt am Main, Germany, 2014; pp. 177-205.

49. Andreff, W. Financial and sporting performance in French football Ligue 1: Influence on the players' market. Int. J. Financ. Stud. 2018, 6, 91. [CrossRef] 
50. Thaler, R.H. Anomalies: The winner's curse. J. Econ. Perspect. 1988, 2, 191-202. [CrossRef]

51. Noll, R.G. The economics of promotion and relegation in sports leagues: The case of English football. J. Sport Econ. 2002, 3 , 169-203. [CrossRef]

52. UEFA. Financial Report 2012/13. 2014. Available online: https://editorial.uefa.com/resources/0213-0f84291f5842-9d380fbc43b1 -1000/2012_13_uefa_financial_report.pdf (accessed on 30 January 2021).

53. UEFA. Financial Report 2018/19. 2020. Available online: https:/ /editorial.uefa.com/resources/025a-0f8430656913-10ccbab24e1 d-1000/2018_19_uefa_financial_report.pdf (accessed on 30 January 2021).

54. Barajas, Á.; Rodríguez, P. Spanish football clubs' finances: Crisis and player salaries. Int. J. Sport Financ. 2010, 5, 52-66.

55. Dietl, H.M.; Franck, E.; Lang, M. Overinvestment in team sports leagues: A contest theory model. Scot. J. Polit. Econ. 2008, 55, 353-368. [CrossRef]

56. Késenne, S. League management in professional team sports with win maximizing clubs. Eur. J. Sport Manag. 1996, 2, 14-22.

57. Quirk, J.; El-Hodiri, M. The Economic Theory of a Professional Sports League. In Government and the Sports Business; Noll, R., Ed.; Brookings Institution: Washington, DC, USA, 1974.

58. Vrooman, J. A Unified theory of capital and labor markets in major league baseball. South. Econ. J. 1997, 63, 594-619. [CrossRef]

59. Carlsson-Wall, M.; Kraus, K.; Messner, M. Performance measurement systems and the enactment of different institutional logics: Insights from a football organization. Manag. Accont. Res. 2016, 32, 45-61. [CrossRef]

60. Késenne, S. Competitive Balance in Team Sports and the Impact of Revenue Sharing. J. Sport Manag. 2006, 20, 39-51. [CrossRef]

61. Késenne, S. The win maximization model reconsidered: Flexible talent supply and efficiency wages. J. Sport Econ. 2006, 7, 416-427. [CrossRef]

62. Gammelsæter, H.; Storm, R.K.; Söderman, S. Diverging Scandinavian approaches to professional football, The Organisation and Governance of Top Football across Europe: An Institutional Perspective; Routledge: Oxon, UK, 2011; pp. 77-92.

63. Szymanski, S. Insolvency in English football. Goddard. In Handbook on the Economics of Professional Football; Goddard, J., Sloane, P., Eds.; Edward Elgar Publishing: Cheltenham, UK, 2014; pp. 100-116.

64. Hamil, S.; Walters, G.; Watson, L. The model of governance at FC Barcelona: Balancing member democracy, commercial strategy, corporate social responsibility and sporting performance. Soccer Soc. 2010, 11, 475-504. [CrossRef]

65. Storm, R.K.; Nielsen, K. Soft budget constraints in professional football. Eur. Sport Manag. Q. 2012, 12, 183-201. [CrossRef]

66. Késenne, S. Revenue sharing and competitive balance in professional team sports. J. Sport Econ. 2000, 1, 56-65. [CrossRef]

67. Storm, R.K.; Nielsen, K. Soft budget constraints in European and US leagues: Similarities and differences. In Disequilibrium Sports Economics: Competitive Imbalance and Budget Constraints; Andreff, W., Ed.; Edward Elgar Publishing: Cheltenham, UK; Northampton, MA, USA, 2015.

68. Deloitte. Eliteseriebarometeret- Et innblikk i økonomien til Norske Toppfotballklubber. 2017. Available online: www.eliteserien. no/nyheter/hat-trick-pa-bunnlinjen/Eliteseriebarometeret\%202017.pdf (accessed on 30 January 2021).

69. Norwegian, F.A. Økonomiske Kriterier for 0. og 1. Divisjon Menn. 2015. Available online: https://www.fotball.no/lov-ogreglement/klubblisens/tl-og-obos/kriterier/okonomiske-kriterier2/\#Toppen (accessed on 30 January 2021).

70. Baade, R.A. Evaluating subsidies for professional sports in the United States and Europe: A public-sector primer. Oxf. Rev. Econ. Policy 2003, 19, 585-597. [CrossRef]

71. Norwegian, F.A. Retningslinjer for Tredjepartseierskap i økonomiske Rettigheter til Spillere. 2016. Available online: www.fotball. no/globalassets/regler-og-retningslinjer/klubblisens/retningslinjer-tredjepartseierskap.pdf (accessed on 30 January 2021).

72. Fort, R. European and North American sports differences (?). Scot. J. Polit. Econ. 2000, 47, 431-455. [CrossRef]

73. Pieper, J. Financial fair play in European football. In When Sport Meets Business-Capabilities, Challenges, Critiques; Wagner, U., Storm, R.K., Nielsen, K., Eds.; Sage: London, UK, 2017; pp. 167-185.

74. Bachmaier, B.; Lammert, J.; Plumley, D.; Wilson, R.; Hovemann, G. Regulatory intensity in English and German professional football. A comparative analysis of national requirements for ensuring financial stability. Sports Bus. Manag. 2018, 8, $276-297$. [CrossRef]

75. PricewaterhouseCoopers. The PricewaterhouseCoopers Financial Review of Scottish Football 2000/2001; PricewaterhouseCoopers: Glasgow, Scotland, 2002.

76. Franck, E. European Club Football after 'Five Treatments' with Financial Fair Play-Time for an Assessment. Int. J. Financ. Stud. 2018, 6, 97. [CrossRef]

77. Beech, J. Finance in the Football Industry. In Managing Football. An International Perspective; Hamil, S., Chadwick, S., Eds.; Butterworth-Heinemann: Oxford, UK, 2010; pp. 119-167.

78. Torres-Pruñonosa, J.; Plaza-Navas, M.A.; Díez-Martín, F.; Prado-Roman, C. The Sources of Knowledge of the Economic and Social Value in Sport Industry Research: A Co-citation Analysis. Front. Psychol. 2020, 11, 1-17. [CrossRef] 